\title{
BOTULINUM-A TOXIN IN THE TREATMENT OF PAINFUL POST-STROKE NOCTURNAL PAROXYSMAL DYSTONIA TRIGGERED BY PERIODIC LIMB MOVEMENTS OF SLEEP
}

\author{
Case report
}

\author{
Pedro A. Kowacs, Hélio A. Ghizoni Teive, Elcio J. Piovesan, \\ Jorge A. Zavala, Lineu C. Werneck
}

\begin{abstract}
Introduction: Sleep disorders presenting involuntary movements may be very annoying to patients, apart from their negative influence on sleep. Objective: To report the use of botulinum typeA toxin (BoNT-A) to manage the case of a patient whose sleep was severely disrupted by episodes of dystonic posturing of the right lower limb triggered by periodic limb movements of sleep (PLMS). Method: A 79-year-old woman with mild post-stroke right hemiparesis presented with recu rrent painful episodes of dystonia of the right lower limb, which disrupted her sleep. The dystonic episodes could also be voluntarily triggered by extension of the right hallux. Polysomnography confirmed that the dystonic episodes we re triggered by PLMS. Twenty units of BoNT-A (20U/500U vial) were injected into her right extensor hal lucis longus. Results: Shortly after BoNT-A was injected, the dystonic symptoms abated, and the patient achieved better sleep efficiency. Conclusion: The PLMS-related involuntary extension of the hallux was p robably triggering the nocturnal post-stroke lower limb dystonic paroxysms. BoNT-A injection into the right extensor hallucis longus was effective in managing this condition and thus resolved the associated disruption of sleep.
\end{abstract}

KEY WORDS: botulinum toxin-A, dystonia, post-stroke dystonia, periodic movements of sleep.

\begin{abstract}
Toxina botulínica tipo A no tratamento da distonia paroxística noturna dolorosa pós-isquemia cerebral desencadeada por movimentos periódicos do sono: relato de caso
\end{abstract}

\begin{abstract}
RESUMO - In trodução: Deso rdens do sono apresentando movimentos involuntários podem ser bastante perturbadoras aos pacientes, além de sua influência negativa no sono. Objetivo: D escrever o uso da toxina botulínica tipo-A (BoNT-A) no manejo do caso de um paciente cujo sono estava gravemente fragmentado por episódios de distonia do membro inferior direito, desencadeados por movimentos periódicos do sono (MPS). Método: Uma paciente com 79 anos portadora de hemiparesia direita leve seqüelar a isquemia ce rebral (AVCl) pro cu rou-nos por episódios dolorosos recorrentes de distonia noturna de seu membro inferior direito, os quais fragmentavam seu sono. Os episódios de distonia também podiam ser desencadeados voluntariamente, por extensão do hálux direito. Uma polisonografia confirmou que os episódios distônicos eram desencadeados pelos MPS. Vinte unidades de BoNT-A (20 U/frasco de $500 \mathrm{U}$ ) foram injetadas no seu extensor longo do hálux. Resultados: Alguns dias após a injeção de BoNT-A os sintomas distônicos re g rediram, e o sono da paciente tornou-se eficiente. Conclusão: As extensões involuntárias do hálux relacionadas aos movimentos periódicos do sono estavam provavelmente desencadeando os paroxismos distônicos noturnos pós-AVCl. A injeção de BoNT-A no extensor longo do hálux foi eficaz no manejo desta condição, resolvedo assim a fragmentação do sono.
\end{abstract}

PALAVRAS-CHAVE: toxina botulínica tipo-A, distonia, distonia pós-AVC, movimentos periódicos do sono.

Se niço de Neurologia, Departamento de Clínica Médica, Hospital de Clínicas, Universidade Federal do Paraná (HC-UFPR), Curitiba, Brasil.

Received 24 November 2005, received in final form 28 June 2006. Accepted 7 August 2006.

Dr. Pedro André Kowacs - Serviço de Neurologia / Departamento de Clínica Médica / HC-UFPR - Rua General Carneiro 181 / $12^{\circ}$ / 1236 - 80060-900 Curitiba PR - Brasil. E-mail: cefaleia@hc.ufpr.br 
Sleep disorders presenting involuntary movements ${ }^{1}$ may be very annoying to patients, apart from their negative influence on sleep. In this group, periodic limb movements of sleep (PLMS) is a well known symptom, whose pathophysiology is just beginning to be understood ${ }^{2}$. Several primary sleep disorders such as restless legs syndrome (RLS), obstructive sleep apnea (OSA), REM behavior disorder (RBD) and narcolepsy may result in the occurrence of PLMS. However, while RLS and associated PLMS may respond to dopamine agonists or to levodopa/dopa-decarboxylase inhibitors, the other conditions do not $^{3}$, and thus deserve specific therapeutic approaches. In some of these patients, the symptoms may occur as bothersome tonic contractions of the anterior tibialis'. The case of a patient presenting painful PLMS who responded to (botulinum type-A toxin) BoNT-A injected into her extensor hallucis longus is described in this paper, and the role of BoNT-A in the therapy of such conditions is discussed. The report was approved by the institutional regulatory committee (CEPSHHC-UFPR).

\section{CASE}

A 79-year-old woman came to us for medical help due to a sleep problem. Nine years before she had had a stroke, which left her with a mild right hemiparesis but with severe, painful nocturnal dystonic episodes in her right leg, which disrupted her sleep. When she consulted us, she was using digoxin, losartan, hydroxizine, slow-release verapamil, baclofen, amitryptiline, sinvastatin and several vitamins. The rest of her medical history was unremarkable, except for arterial hypertension and hypertriglyceridemia. At examination, she was observed to be short and obese $(150 \mathrm{~cm}$ tall and weighing $68 \mathrm{~kg}$ ) with a right hemiparesis 4+ associated to mild hypertonia and increased tendon reflexes on the same side.

Polysomnography revealed 44.9 obstructive apneashypopneas/hour, frequent periodic lower limb movements, with her sleep only reaching phase $\mathrm{II}^{4}$, as it was disrupted by painful right lower limb posturing. Hemogram and biochemistrytests were normal, but computerized tomography imaging of the head revealed a left putaminal infarct with white matter hypodensity extending almost to the convexity. A right maxillary sinus mass with mixed densities, which proved to be a polyp, was also revealed. Due to her being overweight, amitryptiline was reduced to $25 \mathrm{mg} /$ day, and clonazepam $0.25 \mathrm{mg} / \mathrm{night}$ and levodopa/carbidopa $250 / 50 \mathrm{mg}$ were added. Although she rated her improvement at $70 \%$ with therapy, her painful leg symptoms persisted, occurring three times every night, thus fractioning her sleep. At the time, she revealed that she was able to induce the painful episodes during wakefulness by lifting up her right hallux. The phenomenon was witnessed by one of us (PAK) and consisted of a tonic extension of her right toe, associated with a dystonic dorsiflexion of her right foot and a partial flexion of the leg and thigh that could be triggered by a voluntary elevation of her right hallux. The phenomenon was re $f$ e rred to as very painful. A BoNT-A procedure was proposed.

Twenty units of BoNT-A toxin (20 U/500 U vial) were injected into her extensor hallucis longus (HAGT). After 9 days, her painful right limb night posturing subsided, and in spite of her sleep apnea/hypopnea, her sleep was no longer discontinued and she was able to sleep much better.

\section{DISCUSSION}

PLMS were well characterized by Smith ${ }^{5}$, who commented on its similarity with the Babinski sign. In most patients, there is active dorsiflexion of the ankle, dorsiflexion and fanning of the small toes, and dorsiflexion of the great toe. Partial flexion of the knee and hip may occur in one quarter of the patients 5 . Dopaminergic agents such as dopamine agonists and levodopa/dopa decarboxylase inhibitors are considered the treatment of choice for RLS-related PLMS 3 .

Periodic limb movements of sleep may be described as tonic, annoying contractions ${ }^{1}$. They are considered to be spinal automatisms released due to defective suprasegmental inhibition ${ }^{2}$, and were described as occurring associated to several medical conditions, including spinal cord lesions ${ }^{6}$. Paroxysmal dystonia is a known rare complication of subcortical infarcts 7,8 and may also occur as a manifestation of the painful legs and moving toes syndrome, which may be secondary to various peripheral or radicular injuries ${ }^{9}$. In the aforementioned patient, as painful dystonic posturing could be voluntarily triggered by an upward movement of the right hallux, it was reasonable to suppose that the painful tonic contractions of the right lower limb during sleep were dystonic attacks triggered by the patient's Babinski-like PLMS-related movements. BoNT-A is a drug widely used in the therapy of several types of focal dystonia ${ }^{10}$, including dystonic spasms following basal ganglia and thalamic infarcts, and in lower limb extensor hypertonia, as described by Yelnik and Bonan ${ }^{10-12}$.

In the case described here, BoNT-A was able to interfere with the upward movement of the right hallux, thus improving the patient's sleep by interfering with the development of the painful dystonic posturing of the right lower limb, although not interfering with the rest of her PLMS.

We suggest that treatment with BoNT-A should be considered for patients with painful PLMS, as it 
proved effective in reducing the painful limb contractions and improving the quality of sleep of the patient described above.

\section{REFERENCES}

1. Dyken ME, Rodnitzky RL. Periodic, aperiodic, and rhythmic motor disorders of sleep. Neurology 1992;42(Suppl 6):S68-S74.

2. Paradiso G, Khan F, Chen R. Effects of apomorphine on flexorreflex and periodic limb movement. Mov Disord 2002;17:594-597.

3. Stiasny K, Oertel WH, Trenkwalder C. Clinical symptomatology and treatment of restless legs syndrome and periodic limb movement disorder. Sleep Med Rev 2002;6:253-265.

4. Rechtschaffen A, Kales A. Rechtschaffen A, Kales A (eds). A manual of standardised terminology, techniques and scoring system for sleep stages of human subjects. Los Angeles: Brain Information Service/Brain Research Institute, 1968.
5. Smith RC. Relationship of periodic movements in sleep (nocturnal myoclonus) and the Babinski sign. Sleep 1985;8:239-243.

6. Lee MS, Choi YC, Lee SH, Lee SB. Sleep-related periodic leg movements associated with spinal cord lesions. Mov Disord 1996;11:719-722.

7. Merchut MP, Brumlik J. Painful tonic spasms caused by putaminal infarction. Stroke 1986;17:1319-1321.

8. Ghika-Schmid F, Ghika J, Regli F, Bogousslavsky J. Hyperkinetic movement disorders during and after acute stroke: the Lausanne Stroke Registry. J Neurol Sci 1997;152:234-235.

9. Dressler D, Thompson PD, Gledhill RF, Marsdem CD. The syndrome of painful legs and moving toes. Mov Disord 1994;9:13-21.

10. Tintner R, Jankovic J. Focal dystonia: the role of botulinum toxin. Curr Neurol Neurosci Rep 2001;1:337-345.

11. Motoi $Y$, Hattori $Y$, Miwa H, Shina K, Mizuno Y. A case of post-hemiplegic painful dystonia following thalamic infarction with good response to botulinus toxin. Rinsho Shinkeigaku 1997;37:881-886.

12. Yelnik AP, Bonan IV. Post stroke hemiplegia: lower limb benefit from botulinum toxin. Ann Readapt Med Phys 2003;46:281-285. 